\title{
Communication Strategy Used by Bimbingan Masyarakat Islam to Prevent Divorce in Ponorogo
}

\author{
Mohammad Luthfi ${ }^{1}$, M. Rifa' ${ }^{2}$ \\ \{mohammadluthfi@unida.gontor.ac.id ${ }^{1}$, mrifai@unida.gontor.ac.id $\left.{ }^{2}\right\}$
}

University of Darussalam Gontor

\begin{abstract}
This study aims at revealing the communication strategy used by Bimbingan Masyarakat Islam of Ponorogo Regency to prevent divorce problem. The research setting was Ponorogo and the sources of data in this study were Head of Bimbingan Masyarakat Islam, Chair of Extention Workers, and Facilitator. The methods of data collection implemented in this research were interviews, observation and documentation. The results of this study showed that the communication strategy to prevent divorce was undertaken through a marriage guidance and also mediation guidance program. Communicant mapping was done based on the sociological aspects and the needs of the communican which involved the bride, groom, and the conflicting couple in the household. The strategies applied for conveying the messages were lectures, group discussions, question and answer, and interpersonal communication approaches. White board, book of the Foundation of Sakinah Family, and interpersonal communication were also utilized as the mediation aids. Likewise, the communicator also involved some motivators and counselors participating in the certification of Sakinah family, senior counselors, and heads of local religious affairs office of Ponorogo. The finding of this research will be the proper contribution as an effort to prevent divorce.
\end{abstract}

Keywords: Communication Strategy, Bimbingan Masyarakat Islam, Divorce.

\section{Introduction}

Divorce phenomenon is a very crucial social problem and it requires concrete solutions from all aspects. Ponorogo Regency is one of the districts with quite high divorce cases over the past few years. Ponorogo Regency Religious Court decided 2,015 divorce cases in 2015. There were also 2,170 divorces in 2016. Furthermore, the case increased slightly 1,940 divorced couples in the next year[1]. Divorce is evidence of the failure of a married couple to build a household caused by various factors that cannot be overcome and it forces to end in divorce.

Bimbingan Masyarakat Islam of Ponorogo Regency is a government institution that has duties and functions in providing guidance for the community, especially married couples in an effort to realize a family with tranquility, love and mercy. In order to create a tranquility family, Bimbingan Masyarakat Islam conducts divorce prevention activities in the form of marriage guidance and mediation guidance. The implementation of divorce prevention activities carried out by the Islamic Board of Trustees of Ponorogo Regency certainly requires a communication strategy so that the implementation can run according to the plans set, and the main objectives in realizing a family sakinah can be achieved. Communication strategy has a close relationship between the achieved objectives with the consequences (problems) that must be considered in every communication activity carried out, so that the Bimbingan Masyarakat Islam must be able to plan how the consequences are in accordance with the objectives to be achieved[2].

R. Wayne Pace in Effendy said that the main purpose of the communication strategy is to create an understanding between communicator and communicant in understanding messages exchanged and being able to maintain them through motivational activities so that communicant behave as desired by the communicator[3]. Communication strategies are important in every guidance activity carried out by Bimbingan Masyarakat Islam, so that the message delivered can be received and understood as well by the communicant. Thus, there is a common understanding between the communicator in this case the Bimbingan Masyarakat Islam and the communicant. 
Middleton in Cangara said that communication strategies are the best combination of each element of communication including communicator, messages, media, communicant and the best designed effect to achieve optimal communication goals[4]. In the context of the prevention of divorce carried out by the Bimbingan Masyarakat Islam of Ponorogo Regency, the first step that must be taken is to map the communicant before the divorce prevention activities are carried out and then to determine the message that fits the needs and expectations of the communicant. Choosing media as a channel in conveying communication messages as the message delivered through different media will also have a different influence on the communication made. Finally, determining the communicator conveying the communication message includes aspects of credibility and attractiveness possessed by communicator in communication. Communicator credibility is the level of trust given by the communicant to the communicator because of the honesty, expertise and ethics possessed by the communicator. While the attractiveness of the communicator will be able to change the attitude and behavior of the communicant. Attractive communicators tend to be favored by the communicant due to the similarities between the sociological, psychological and anthropological that can bring sympathy to the communicator[5]. For this reason, the authors are interested in examining how the communication strategy used by Bimbingan Masyarakat Islam of Ponorogo Regency in preventing divorce.

\section{Research Methodology}

This research uses desciptive qualitative approach. This approach is intended to understand what is experienced by research subjects such as perception, attitudes, behavior and motivation holistically. Kriyantono in his book Communication Research says that the main purpose of the descriptive approach is to describe systematically, factually and accurately about the facts, characteristics and relationships between phenomena investigated[6].

Data collection is done through interviews, observation and documentation. The interview was conducted with the Head of Section of Bimbingan Masyarakat Islam of Ponorogo Regency, Chair of Ponorogo Regency Islamic Community Extension Worker Group and Ponorogo Regency Islamic Community Facilitator. Observation is carried out in marriage guidance activities for bride and groom couples. The documents used were divorce data from the Ponorogo Religious Court, data on marital guidance activities and mediation activities conducted by the Islamic Community Guidance of Ponorogo Regency in 2015-2017 as supporting data in this study. The location of this study was in the office of the Bimbingan Masyarakat Islam of Ponorogo Regency.

\section{Research Finding and Discussion}

The results showed that the communication strategy used by Bimbingan Masyarakat Islam of Ponorogo Regency was through a marriage guidance program as well as mediation guidance program. The communication strategy undertaken by Bimbingan Masyarakat Islam had a goal to be achieved, namely preventing divorce

The communicant mapping strategy in divorce prevention activities was based on sociological and communicant needs aspects. Marriage guidance program is given to the bride and groom who will get married. Every bride and groom who had registered at local religious affairs offices was included marriage guidance program for 2 days with an estimated time of 8 hours per day. This program provided education to the bride and groom couples on how to build a strong and harmonious family, so that they had sufficient knowledge and provisions in preparing the marriage. Having got marriage, they could build a family that was confident and able to solve every problem arising in the family. The mediation program was given to married couples who had family problems. Bimbingan Masyarakat Islam provided a mediating space to solve problems with an orientation to problem solving solutions that triggered the cracking of interpersonal relationships.

Communication messages conveyed in marriage guidance program were material on the foundation of building tranquility family, planning a solid marriage, the dynamics of marriage, preparing family needs and a qualified generation, managing conflict in the family as well as material on family health including reproductive health. Message material tailored to the needs of participants in this case was the bride and groom who would get married. The 
strategy for delivering packaging messages was through lectures as an introduction, then it was continued with group discussions guided by the facilitator. Message delivery focused more on group discussions with the aim that the message delivered was maximally absorbed by participants. As for mediation activities, the message was conveyed by the method of interpersonal communication in order to build good interpersonal relations between the mediator and the communicant. The establishment of good interpersonal relationships between mediators and married couples provided space for them to convey any problems that arise in the family. With the openness and honesty, each participant would find a concrete solution and the resulting decision became a good and acceptable decision.

The media used in divorce prevention activities were adjusted to the message material delivered. When communication activities were carried out for marriage guidance program, the media used were LCD projectors, blackboards, Sakinah Family Foundation books, and group discussions. The selection of the media was done so that the channels used in the delivery of marriage guidance material had maximum influence in changing the attitudes and behavior of the communicant. As for mediation activities, the media used were directed to the medium of interpersonal communication, so that the mediation process could run more optimally. Therefore, each participant could provide a direct response to the communication message delivered.

The communicator selection strategy was based on aspects of credibility, competence and attractiveness possessed by communicator. Communicator involved in marriage guidance program was facilitator who had taken part in the certification of motivational family and counselor. While for mediation activities, the communicator invited as a mediator was a senior counselor and head of the Office of Religious Affairs in Ponorogo.

\section{Conclusion}

The communication strategy used by Bimbingan Masyarakat Islam of Ponorogo Regency in an effort to prevent divorce is carried out through marriage guidance activities for bride and groom couples and guid ance on mediation for married couples in conflict. Communicant mapping based on sociological aspects and the needs of communicant is also conducted to minimize the problem. The message was delivered in the form of lectures, group discussions as well as interpersonal communication. The media used are the blackboard, the book of the foundation of tranquility, love and mercy family, and the medium of interpersonal communication. The communicator involved is facilitator who have participated in the certification of motivator and tranquility family counselor, senior counselor and head of local religious affair offices of Ponorogo Regency.

The substance of this study provides recommendations to the Bimbingan Masyarakat Islam of Ponorogo Regency to always play an active role in providing guidance on religious education for the community, especially married couples. Therefore they have sufficient knowledge about the main purpose of marriage. Bimbingan Masyarakat Islam synergizes with related agencies and socio-religious organizations to jointly provide guidance to the community of counseling and mediation activities as an effort to improve the quality of life in a sturdy and harmonious household, hence the divorce rates can be minimized.

\section{Reference}

[1] TIM, "Dokumen Perceraian Pengadilan Agama Ponorogo," Ponorogo, 2018.

[2] H. A. Susanti, "Strategi komunikasi badan kependudukan dan keluarga berencana nasional (bkkbn)," J. Komun. ASPIKOM, 2015.

[3] Onong Uchjana Effendy, Ilmu Komunikasi; Teori dan Praktek. Bandung: Remaja Rosdakarya, 2013.

[4] Hafied Cangara, Perencanaan dan Strategi Komunikasi. Jakarta: Rajawali Pers, 2013.

[5] Y. S. U. \& S. Fatonah, "Evaluasi Strategi Komunikasi Konselor BP4 dalam Mencegah Perceraian," CHANNEL, vol. 3, no. 2, pp. 89-99, 2015.

[6] Rachmat Kriyantono, Teknis Praktis Riset Komunikasi. Jakarta: Kencana Prenadamedia Group, 2014. 